\title{
IMPAK PANDEMIK COVID-19 TERHADAP PENYERAGAMAN DAN PENYELARASAN FATWA DI MALAYSIA
}

\section{(The Impact of the COVID-19 Pandemic on the Standardization and Coordination of Fatwas in Malaysia)}

Mohd. Kamel Mat Salleh*

mohdkamel@uitm.edu.my

Adibah Bahori

adibahbahori@uitm.edu.my

Muhammad Firdaus Abdul Manaf

firdausmanaf@uitm.edu.my

Nursafra Mohd. Zhaffar

nursafra@uitm.edu.my

Akademi Pengajian Islam Kontemporari, Universiti Teknologi MARA.

Sirajuddin Suhaimee

siraj@islam.gov.my

Bahagian Penyelidikan, Jabatan Kemajuan Islam Malaysia, Putrajaya.

Pengarang koresponden (Corresponding author): *

Rujukan artikel ini (To cite this article): Mohd. Kamel Mat Salleh, Adibah Bahori, Muhammad Firdaus Abdul Manaf, Nursafra Mohd. Zhaffar dan Sirajuddin Suhaimee. (2021). Impak pandemik COVID-19 terhadap penyeragaman dan penyelarasan fatwa di Malaysia. Kanun: Jurnal Undang-undang Malaysia, 33(2), 269-286 .http://doi.org. 10.37052/kanun.33(2)no4

\begin{tabular}{|llllll|}
\hline $\begin{array}{l}\text { Peroleh: } \\
\text { Received: }\end{array}$ & 16/12/2020 & $\begin{array}{l}\text { Semakan: } \\
\text { Revised }\end{array}$ & 4/5/2021 & $\begin{array}{l}\text { Terima: } \\
\text { Accepted: 20/5/2021 }\end{array}$ & $\begin{array}{l}\text { Terbit dalam talian: 6/7/2021 } \\
\text { Published online }\end{array}$
\end{tabular}

\footnotetext{
Abstrak

Pandemik COVID-19 telah mewujudkan landskap dan norma baharu dalam kehidupan masyarakat Malaysia, termasuk yang berkaitan dengan amalan keagamaan orang Islam. Pandemik ini melibatkan penangguhan pelaksanaan solat Jumaat, solat berjemaah di masjid serta

(C) Dewan Bahasa dan Pustaka. 2021. This work is licensed under the term of the Creative Commons Attribution (CC BY) (http://creative commons.org/licenses/by/4.0/) 
surau seluruh Malaysia serta hukum syarak yang lain. Keputusan ini selaras dengan pandangan hukum yang diputuskan oleh Jawatankuasa Muzakarah Khas Majlis Kebangsaan Bagi Hal Ehwal Ugama Islam Malaysia (Jawatankuasa Muzakarah MKI) yang diurusetiakan oleh Jabatan Kemajuan Islam Malaysia yang kemudiannya difatwakan pada peringkat negeri. Carta alir pengeluaran fatwa ini membuka dimensi baharu kepada penyeragaman dan penyelarasan fatwa di Malaysia terhadap keputusan Jawatankuasa Muzakarah MKI yang mempunyai kepentingan nasional. Sedangkan selama ini terdapat kekangan yang menyebabkan fatwa sukar untuk diseragamkan dan diselaraskan atas kapasiti fatwa ialah hak eksklusif negeri. Kajian ini dijalankan untuk menjawab persoalan adakah benar fatwa itu sukar untuk diselaraskan di Malaysia sedangkan undang-undang negeri memperuntukkan bahawa penyelarasan boleh berlaku melalui Jawatankuasa Muzakarah MKI dan isu yang melibatkan kepentingan nasional. Kajian berbentuk kualitatif ini menggunakan kaedah analisis kandungan dengan merujuk peruntukan undang-undang yang membolehkan penyelarasan dan penyeragaman berlaku. Kajian mendapati bahawa penyeragaman dan penyelarasan fatwa bukanlah suatu yang sukar dilaksanakan. Hukum Syarak berhubung dengan COVID-19 telah mencetuskan impak besar dan menjadi penanda aras kepada usaha penyelarasan dan penyeragaman fatwa di Malaysia.

Kata Kunci: COVID-19, penyeragaman dan penyelarasan fatwa, Jawatankuasa Muzakarah MKI, kepentingan nasional

\begin{abstract}
The COVID-19 pandemic has created new landscapes and norms in the Malaysian society, including issues related to Muslims'religious practices. Some of the practices affected include the postponement of the weekly Friday prayer, congregational prayers in mosques and suraus nationwide, and several other related matters. The fatwas made amidst a health crisis are in line with the legal view decided by the Special Muzakarah Committee of the National Council for Islamic Religious Affairs (MKI), which is supervised under the Department of Islamic Development Malaysia (JAKIM) and later overseen at the state level. The streamlining of fatwa issuance opens a new dimension to the standardisation and coordination of fatwas in Malaysia initiated by the decision, which has national significance, by the MKI. In contrast to previous practices, which position fatwas as the state's exclusive right, efforts to standardise and coordinate fatwas faced constraints. This study seeks to answer
\end{abstract}


whether fatwas are challenging to coordinate in Malaysia despite state laws' provisions asserting that coordination can occur through the MKI and issues of national interests. This qualitative study uses document analysis for legal provisions that allow for coordination and standardisation. The findings of this study explain that the standardisation and coordination of fatwas are not strenuous to implement. The Syariah decisions regarding COVID-19 have had a considerable impact and have become a benchmark for further coordination and standardisation of other fatwas in Malaysia.

Keywords: COVID-19, standardization and coordination of fatwas, MKI Muzakarah Committee, national interest

\section{PENDAHULUAN}

COVID-19 mula memasuki Malaysia dengan kes yang pertama dikesan positif pada 3 Februari 2020 (http://covid-19.moh.gov.my). Sejak tarikh tersebut, kes positif semakin bertambah dari semasa ke semasa dan sehingga kini penularannya kini masih belum terhenti. Rantaian COVID-19 belum terputus dan masih tersebar di merata dunia. Dalam konteks Malaysia, kerajaan telah mengambil langkah memperkenalkan Perintah Kawalan Pergerakan (PKP) diikuti kemudiannya dengan Perintah Kawalan Pergerakan Bersyarat (PKPB) dan Perintah Kawalan Pergerakan Pemulihan (PKPP). Di sesetengah tempat, kerajaan melaksanakan Perintah Kawalan Pergerakan Diperketatkan (PKPD) bergantung pada zon dan jumlah positif kes di lokasi berkenaan (Akta Pencegahan dan Pengawalan Penyakit Berjangkit, 1988, Akta Polis, 1967).

Pandemik COVID-19 telah mengubah landskap kehidupan kepada kebiasaan baharu, menyebabkan negara di dunia termasuk Malaysia mengambil langkah luar biasa bagi memastikan negara dapat bebas daripada pandemik itu. Pandemik ini turut membabitkan persoalan hukum syarak dan kaedah pelaksanaan ibadah yang tidak pernah berlaku sebelumnya. Antara pelaksanaan ibadah yang menimbulkan pelbagai polemik hukum pada peringkat awal yang menjadi pertikaian dalam kalangan umat Islam termasuklah penangguhan pelaksanaan solat Jumaat dan solat berjemaah di masjid serta surau seluruh Malaysia, penjarakan saf dalam solat berjemaah, pelaksanaan solat terawih dan solat hari raya di rumah kediaman, bayaran zakat tanpa amil dan beberapa persoalan lain. 
Dalam konteks pentadbiran fatwa di Malaysia, satu lembaran baharu dibuka dalam penyeragaman dan penyelarasan fatwa di antara negeri secara holistik. Suatu hal yang jarang berlaku apabila semua pandangan hukum yang diputuskan oleh Jawatankuasa Muzakarah Majlis Kebangsaan Bagi Hal Ehwal Ugama Islam (MKI) diterima, dilaksanakan dan diwartakan pada peringkat Negeri dalam kadar segera. Penyelarasan ini dapat dilaksanakan berdasarkan kepada peruntukan dalam Akta/ Enakmen/ Ordinan Pentadbiran Agama Islam Negeri dan fatwa yang berkuat kuasa di negeri-negeri. Walaupun tidak semua negeri mempunyai peruntukan tersebut, tetapi fatwa berkait COVID-19 ini telah berjaya diterima dan dilaksanakan pada peringkat negeri (Akta, Enakmen dan Ordinan Pentadbiran Undang-Undang Islam Negeri-Negeri, Enakmen Fatwa Negeri Sabah 2004 dan Enakmen Mufti dan Fatwa Kedah Darul Aman 2008). Oleh itu, kajian ini bertujuan untuk menjelaskan isu penyeragaman dan penyelarasan fatwa di Malaysia. Selain itu, kajian ini juga turut menjelaskan peranan Jawatankuasa Muzakarah MKI dalam penyelarasan fatwa di Malaysia seterusnya menganalisis peruntukan undang-undang bagi tujuan penyelarasan fatwa di Malaysia.

\section{METODOLOGI KAJIAN}

Kajian ini dijalankan secara kualitatif menggunakan kaedah analisis dokumen. Terdapat empat jenis dokumen yang dianalisis, iaitu keputusan Jawatankuasa Muzakarah MKI, fatwa negeri dalam isu berkaitan dengan hukum COVID-19, dokumen dalam bentuk statut Pentadbiran Agama Islam Negeri-Negeri dan artikel penyelidikan yang berkaitan dengan skop kajian.

Pengkaji mengumpulkan data mengenai fatwa berkaitan dengan hukum COVID-19 bermula dari 15 Mac 2020 hingga 24 Jun 2020. Sebanyak 14 keputusan Jawatankuasa Muzakarah MKI diteliti serta disokong oleh dokumen lain. Data berkaitan dengan skop kajian dianalisis menggunakan kaedah perbandingan berterusan seperti yang disarankan oleh Merriam (2009) dan Harding (2013). Kaedah ini membolehkan pengkaji membuat perbandingan antara set data daripada bentuk dokumen yang berbeza; keputusan Jawatankuasa Muzakarah MKI dan Fatwa negeri-negeri.

\section{FATWA BERKAITAN DENGAN COVID-19 DALAM KONTEKS MALAYSIA}

Kronologi pelaksanaan fatwa negeri berhubung dengan isu COVID-19 bermula melalui Mesyuarat Jawatankuasa Muzakarah Khas MKI yang 
diadakan pada 15 Mac 2020 bagi membincangkan berkenaan dengan dua isu utama, iaitu cadangan penangguhan semua aktiviti masjid dan surau terutama solat berjemaah dan solat Jumaat. Begitu juga dengan kaedah pengurusan jenazah akibat COVID-19.

Selepas itu, sehingga Julai 2020, sebanyak tujuh siri Mesyuarat Jawatankuasa Muzakarah Khas telah dilaksanakan bagi membincangkan isu lain yang berkaitan. Hasilnya beberapa resolusi telah dikeluarkan untuk dilaksanakan pada peringkat negeri. Antara ketetapan yang telah disepakati dalam mesyuarat tersebut termasuklah keputusan berkenaan dengan isu penangguhan semua aktiviti masjid dan surau (termasuk solat berjemaah dan solat Jumaat), tatacara pengurusan jenazah orang Islam yang meninggal dunia akibat virus COVID-19 (Corona Virus) di Malaysia, kaedah melihat anak bulan Ramadan, Syawal dan Zulhijah ketika Perintah Kawalan Pergerakan (PKP- COVID-19), penyelarasan kaedah pembayaran zakat fitrah dalam tempoh Perintah Kawalan Pergerakan (PKP-COVID-19), kaedah solat Jumaat dan ibadah bulan Ramadan sepanjang tempoh Perintah Kawalan Pergerakan (PKP- COVID-19), panduan hukum ujian saringan dan prosedur rawatan pesakit COVID-19 pada bulan Ramadan, kedudukan saf solat jemaah ketika Perintah Kawalan Pergerakan (PKP) COVID-19, garis panduan sambutan hari raya ketika perintah kawalan pergerakan (PKP) COVID-19, garis panduan solat fardu dan sunat secara berjemaah dalam tempoh pasca-PKP COVID-19, cadangan aktiviti di masjid dan surau dalam tempoh Perintah Kawalan Pergerakan Pemulihan (PKPP) COVID-19, garis panduan pelaksanaan ibadah korban dalam tempoh Perintah Kawalan Pergerakan Pemulihan (PKPP) dan pelaksanaan haji bagi Musim Haji 1441 Hijrah (2020) berikutan dengan penularan COVID-19.

Uniknya, keputusan muzakarah ini diterima pada peringkat negeri, dan dilaksanakan dalam kadar segera. Atas dasar kepentingan nasional, fatwa dapat diseragamkan membuktikan bahawa penyelarasan fatwa di Malaysia boleh berlaku mengikut saluran dan peruntukan undang-undang. Hal ini membuka ruang untuk perbincangan sejauh manakah fatwa dapat diselaraskan di Malaysia? Apakah peruntukan yang boleh menjadi sandaran kepada penyelarasan fatwa di Malaysia?

\section{ISU PENYELARASAN DAN PENYERAGAMAN FATWA DI MALAYSIA}

Dalam Perkara 74(2) dan Butiran 1, Senarai Negeri, Jadual Kesembilan, Perlembagaan Persekutuan memperuntukkan bahawa semua perkara 
berkaitan dengan agama Islam dan hukum syarak adalah di bawah bidang kuasa negeri termasuk hal ehwal kefatwaan (Perlembagaan Persekutuan 2006). Apabila pengurusan fatwa ini diuruskan oleh negeri masingmasing, maka banyak fatwa yang diputuskan berbeza antara satu negeri dengan negeri lain, seperti perbezaan fatwa dalam isu merokok dan hukum pelaburan dalam ASN dan ASB. Begitu juga hukum dan fatwa tertentu dikeluarkan oleh satu negeri tetapi tidak pada negeri-negeri lain disebabkan isu tersebut hanya khusus untuk negeri berkenaan seperti hukum berkaitan dengan tanah wakaf dan ajaran sesat yang terdapat di sesetengah negeri.

Walau bagaimanapun, inisiatif dan hasrat penyelarasan fatwa ini tetap diusahakan untuk direalisasikan melalui penubuhan Jawatankuasa Muzakarah Majlis Kebangsaan bagi Hal Ehwal Ugama Islam Malaysia yang ditubuhkan pada tahun 1970 berdasarkan peruntukan Perkara 11 Peraturan Majlis Kebangsaan Bagi Hal Ehwal Ugama Islam Malaysia (MKI) (awal penubuhan disebut sebagai Jawatankuasa Fatwa MKI). Menurut Mahamad Naser Disa (2011), berdasarkan Perkara 3(2) Perlembagaan Persekutuan, Raja-raja Melayu sebagai ketua agama boleh memberikan persetujuan untuk penyelarasan amalan dan pematuhan dalam hal ehwal agama Islam. Maksudnya, penubuhan Jawatankuasa ini walaupun secara pentadbiran, namun berpengaruh besar dalam penggubalan dasar tentang Islam dan hukum-hukumnya.

Peraturan 14 MKI menyatakan secara jelas tugas Jawatankuasa, iaitu menimbang, memutuskan dan mengeluarkan fatwa atas apa-apa perkara berkenaan dengan agama Islam yang dirujuk kepadanya oleh Majlis RajaRaja. Jawatankuasa ini akan mengemukakan penemuan fatwa yang tertentu kepada MKI yang kemudiannya akan mengemukakannya bersama-sama dengan pengesyoran kepada Majlis Raja-Raja untuk dibincangkan oleh Jawatankuasa Fatwa Negeri bagi menentukan fatwa seterusnya untuk diwartakan di negeri berkenaan.

Muzakarah juga merupakan medium penyelidikan dan penyelarasan serta penyeragaman fatwa bagi negeri-negeri di Malaysia. Muzakarah selaras dengan prosedur pengeluaran fatwa di negeri bahawa fatwa hanya boleh dikeluarkan oleh para ashab al-Samahah mufti bersama-sama dengan Jawatankuasa Fatwa Negeri melalui peruntukan undang-undang yang berkuat kuasa berkaitan dengan fatwa di negeri-negeri. Muzakarah tidak menyentuh atau menjejaskan kuasa Ketua Agama Islam Negeri dalam urusan pengeluaran fatwa. Perkara 16 Peraturan MKI memperuntukkan, tiada apaapa jua keputusan Majlis (MKI) yang boleh menyentuh kedudukan, hak, kelebihan, kedaulatan dan kuasa yang ada pada Raja Pemerintah sebagai 
Ketua Agama Islam seperti yang termaktub dalam Perlembagaan Malaysia dan Perlembagaan Negeri berkenaan (Peraturan Majlis Kebangsaan Bagi Hal Ehwal Ugama Islam Malaysia 2013).

Keahlian Muzakarah terdiri daripada semua mufti negeri dan ahli. Mereka dilantik oleh Majlis Raja-Raja yang mewakili pelbagai latar belakang seperti alim ulama, golongan profesional dan pakar serta wakil perkhidmatan kehakiman dan undang-undang. Penguasaan ilmu ikhtisas diaplikasikan bagi membincangkan isu-isu hukum yang berlegar dalam masyarakat semasa, terutama yang melibatkan kepentingan kesucian agama Islam. Hal ini tidak tertakluk pada permasalahan fikah dan akidah sematamata, malah mencakupi pelbagai isu termasuklah pembangunan negara dalam bidang ekonomi, ilmu pengetahuan sains dan perubatan, sosial, perundangan dan sebagainya (Kompilasi Pandangan Hukum Jawatankuasa Muzakarah Kebangsaan 2018). Keputusan dimuktamadkan secara jamaie (kolektif) bagi menunjukkan kesepakatan dan kesepaduan pemikiran dalam kalangan ahli Muzakarah.

Hakikatnya, terdapat beberapa penulisan tentang kepentingan dan cadangan penyelarasan fatwa telah dikemukakan oleh para pengkaji tempatan. Zaini (2005) yang berpandangan bahawa fatwa di Malaysia sukar untuk diseragamkan kerana penguatkuasaan fatwa di bawah bidang kuasa negeri. Beliau turut membuat sorotan berkenaan dengan tujuan penubuhan Jawatankuasa Fatwa pada peringkat Kebangsaan yang berperanan sebagai badan penyelarasan fatwa terutamanya pandangan yang diputuskan hasil daripada apa-apa perkara yang dirujuk kepadanya oleh Majlis Raja-Raja.

Mohd. Mohadis Yasin (2007) turut memberikan pandangan yang sama, dan menekankan bahawa masih terdapat kekurangan serta saranan yang perlu diberikan perhatian terharap usaha memperkasa dan memartabatkan institusi fatwa di Malaysia. Penyelarasan agak sukar dilakukan kerana Mufti dan Jawatankuasa Fatwa Negeri yang mempunyai bidang kuasa sendiri dalam urusan pentadbiran fatwa di negeri masing-masing. Oleh itu, berlaku perbezaan fatwa antara negeri-negeri meskipun melibatkan persoalan yang sama. Maka di sinilah letaknya kepentingan Jawatankuasa Muzakarah bagi menyelaras fatwa dan hukum Islam di semua negeri.

Pandangan ini turut dikongsi oleh Arik Sanusi (2010) dan Lokmanulhakim (2013). Isu tersebut masih berlarutan sehingga kini dan tiada penyelesaian seperti yang dikemukakan dalam kajian Muhammad Ikhlas Rosele et al. (2013). Satu idea baharu pernah dicetuskan melalui cadangan pelantikan seorang Mufti Negara tetapi pandangan ini ditolak kerana skop tugas tersebut telah dijalankan oleh Jawatankuasa Fatwa 
Kebangsaan ketika itu (Ahmad Hidayat, B., 2012; Mohamed Azam, M. A., 2012).

Muhammad Fathullah Al Haq dan Jasni (2017) mengemukakan beberapa input lain punca penyelarasan fatwa masih belum berjaya, antaranya termasuklah tidak semua negeri memasukkan peruntukan khusus untuk menerima pakai nasihat dan syor Jawatankuasa Fatwa Kebangsaan. Walau bagaimanapun, dari segi amalan, negeri-negeri berkenaan masih menerima pakai nasihat dan syor Jawatankuasa Fatwa Kebangsaan. Bidang kuasa khusus negeri-negeri juga menyebabkan sesebuah negeri menangguhkan perbincangan sesuatu fatwa yang diputuskan oleh Jawatankuasa Muzakarah MKI. Terdapat juga situasi apabila negeri hanya membincangkan isu yang timbul dalam lingkungan negeri sahaja dalam Mesyuarat Jawatankuasa Fatwa Negeri tanpa melibatkan isu yang dibincangkan pada peringkat Kebangsaan. Selain itu, terdapat negeri yang tidak membentangkan sepenuhnya kertas keputusan yang dibuat pada peringkat Jawatankuasa Muzakarah MKI, tetapi kertas keputusan tersebut dikepilkan dalam mesyuarat sebagai rujukan kepada ahli. Isu yang menjadi halangan penerimaan dan penyelarasan fatwa ialah keputusan Muzakarah itu tidak berjaya dihadamkan oleh AJK Fatwa Negeri kerana mereka tidak berada dalam proses pengeluaran dan perbincangan keputusan yang dipersetujui pada peringkat Muzakarah.

Fathullah al-Haq dan Jasni (2017) mencadangkan langkah-langkah berikut hendaklah dilaksanakan bagi merealisasikan penyelarasan dan penyeragaman fatwa di Malaysia. Antaranya termasuklah Jabatan Mufti Negeri mengambil langkah khas untuk menerima pakai keputusan Jawatankuasa Muzakarah MKI dan juga meraikan fatwa yang pernah diputuskan oleh negeri-negeri yang lain di negara ini. Beberapa penambahbaikan seperti sistem pengurusan fatwa, memperbanyak mesyuarat penyelarasan, meningkatkan pengetahuan dan kemahiran pegawai fatwa serta meluaskan kefahaman fatwa kepada ahli muzakarah dan masyarakat hendaklah dipertingkatkan.

Walaupun banyak idea dan cadangan dikemukakan, penyelarasan dan penyeragaman ini masih belum berjaya. Terbaharu, Muhamad Miziazam et al. (2018), menjelaskan bahawa tiada penyelarasan fatwa di Malaysia menyebabkan ada keperluan untuk penggubalan satu garis panduan bagi mengatasi permasalahan ketidakselarasan dan keseragaman fatwa di Malaysia. Kumpulan pengkaji tersebut masih mencadangkan kajian akan datang yang lebih konkrit untuk mengisi kekosongan atau kelompangan bagi menyelesaikan masalah penyelarasan fatwa sekali gus menghilangkan 
kekeliruan masyarakat Islam terhadap ketetapan hukum atau fatwa di Malaysia.

\section{KEKANGAN PENYELARASAN DAN PENYERAGAMAN FATWA}

Perbincangan di atas jelas menunjukkan bahawa masih terdapat kekangan dan kesukaran dalam usaha penyelarasan dan penyeragaman fatwa di Malaysia. Terdapat beberapa faktor dan kekangan yang menyebabkan fatwa di Malaysia sukar untuk diseragamkan dan diselaraskan, antaranya termasuklah bidang kuasa mengeluarkan fatwa yang terletak di bawah bidang kuasa negeri-negeri di Malaysia seterusnya menguatkuasakan dan mewartakan fatwa. Walaupun kewujudan Jawatankuasa Muzakarah MKI adalah untuk menyelaraskan fatwa melalui pandangan hukum yang dikeluarkan, namun terdapat kecenderungan negeri meminda teks, sighah dan keputusan hukum yang diputuskan oleh Muzakarah (Lokmanulhakim, H., 2013).

Kajian Zulfaqar (2013) mendapati dari tahun 2000 hingga 2009, sebanyak 149 isu hukum telah dibincangkan pada peringkat Jawatankuasa Muzakarah MKI. Daripada 149 pandangan hukum tersebut mendapati sebanyak 115 fatwa atau $77.18 \%$ daripadanya mempunyai persamaan isu dengan sedikit perbezaan tajuk dengan yang dibincangkan pada peringkat Jawatankuasa Fatwa Negeri.

Apabila diperincikan peranan Yang di-Pertuan Agong (YDPA) dan Sultan/Raja sebagai ketua Agama Islam di negeri-negeri, memberi maksud kuasa mutlak perkara yang berhubung dengan agama Islam dan hukum syarak terletak di bawah kuasa baginda. Maka apabila suatu keputusan berkaitan dengan fatwa diperkenankan oleh baginda dan berbeza daripada pandangan hukum di negeri lain, keputusan ini wajar dihormati, diterima dan dipatuhi oleh semua pihak.

Mengikut carta alir Mesyuarat Jawatankuasa Muzakarah MKI, jika negeri berhasrat menjadikan pandangan hukum sebagai fatwa, ia akan dibawa untuk proses pengeluaran fatwa di negeri masing-masing. Setiap jawatankuasa fatwa negeri dianggotai oleh pakar yang dilantik dan mempunyai kepakaran tersendiri dalam bidang masing-masing. Situasi ini membuka ruang kepada perbahasan yang mungkin berbeza daripada yang telah diputuskan pada peringkat Muzakarah.

Namun begitu, pengkaji optimis bahawa penyelarasan fatwa boleh berlaku dengan baik terutama dalam situasi COVID-19 yang melanda. Lebih-lebih lagi, terdapat keperluan terkini yang mendesak terhadap hukum 
yang perlu diputuskan secara kolektif. Sementara itu, kebergantungan negeri kepada keputusan Jawatankuasa Muzakarah MKI sebagai badan penyelarasan fatwa juga berada pada tahap yang optimum. Oleh itu, kajian ini bertujuan melihat impak COVID-19 terhadap penyeragaman dan penyelarasan fatwa di Malaysia.

\section{MEKANISME PENYELARASAN DAN PENYERAGAMAN FATWA DI MALAYSIA}

Penyeragaman dan penyelarasan fatwa di Malaysia bukanlah suatu yang mustahil untuk dilaksanakan. Dari sudut teori, perkara ini telah diperuntukkan dalam Akta, Enakmen dan Ordinan Pentadbiran Agama Islam Negeri-Negeri yang terkandung dalamnya peruntukan berkaitan fatwa termasuk Enakmen Mufti dan Fatwa (Kedah Darul Aman) 2008 dan Enakmen Fatwa Sabah (2004). Proses ini membabitkan dua (2) peruntukan iaitu "Fatwa yang Ada Hubungan dengan Kepentingan Nasional" dan "Menerima Pakai Nasihat dan Syor Jawatankuasa Fatwa Kebangsaan".

Sebagai contoh, dalam Enakmen Pentadbiran Agama Islam (Negeri Selangor) 2003, Seksyen 51 memperuntukkan bahawa mana-mana perkara yang menyentuh kepentingan nasional hendaklah dikemukakan kepada Majlis dan seterusnya mengemukakan syor tersebut kepada Duli Yang Maha Mulia Sultan untuk isu tersebut dirujuk kepada Jawatankuasa Fatwa Kebangsaan melalui Majlis Raja-Raja. Dalam Seksyen 52 pula, enakmen yang sama, memperuntukkan bahawa Jawatankuasa Fatwa Negeri hendaklah menerima pakai nasihat dan syor Jawatankuasa Fatwa Kebangsaan melalui apa-apa yang telah dipersetujui oleh Majlis Raja-Raja.

Sewajarnya melalui dua peruntukan ini dapat dijadikan penanda aras ke arah penyelarasan fatwa di Malaysia. Namun begitu, beberapa permasalahan masih wujud kerana tidak semua negeri mempunyai peruntukan tersebut. Peruntukan ini tidak terdapat dalam Akta dan Enakmen Wilayah Persekutuan, Kelantan, Terengganu dan Pahang. Seksyen ini menjelaskan bahawa apa-apa isu yang dilihat mempunyai kepentingan awam akan dirujuk kepada keputusan Jawatankuasa Fatwa Kebangsaan (Jawatankuasa Muzakarah MKI) untuk disyorkan kepada Majlis Raja-Raja agar fatwa berkaitan dengannya dikeluarkan. Empat Negeri ini termasuk Negeri Sembilan tidak memasukkan peruntukan "Menerima Pakai Nasihat Dan Syor Jawatankuasa Fatwa Kebangsaan” ini dalam Akta, Enakmen dan Ordinan Pentadbiran Agama Islam Negeri-Negeri.

Pada 4-6 Disember 2009, dalam Persidangan Mufti-Mufti Seluruh 
Malaysia Kali Kelima, Penasihat Undang-Undang JAKIM ketika itu, Tuan Faisal Ahmad Sabri telah mencadangkan supaya Enakmen Mufti dan Fatwa (Kedah Darul Aman) 2008 diambil dan dicadangkan kepada Majlis RajaRaja untuk diseragamkan di semua negeri dan meminta supaya cadangan ini dikemukakan kepada Jawatankuasa Teknikal Undang-Undang Syarak dan Sivil untuk pertimbangan. Jawatankuasa Teknikal Undang-Undang Syarak dan Sivil pula dalam persidangannya pada 14-15 Mei 2010 memutuskan agar satu undang-undang fatwa yang seragam diwujudkan untuk diguna pakai di seluruh Malaysia dengan menjadikan Enakmen Fatwa Sabah dan Enakmen Mufti dan Fatwa Kedah sebagai asas perbandingan (Mohd. Hamzah, I., 2014).

Peruntukan undang-undang ini memberi maksud wujudnya pengaruh Jawatankuasa Fatwa Kebangsaan (Jawatankuasa Muzakarah MKI) dalam usaha penyelarasan dan penyeragaman fatwa di antara negeri-negeri di Malaysia. Namun begitu, pelaksanaan peruntukan ini masih tidak menyeluruh kerana masih ada negeri yang belum memasukkan peruntukan ini dalam akta dan enakmen Pentadbiran Agama Islam Negeri-Negeri.

Dari segi kepraktikalannya, peruntukan ini telah berjaya menyelaraskan beberapa pandangan hukum yang dikeluarkan oleh Jawatankuasa Muzakarah MKI untuk difatwakan di negeri-negeri. Sehingga Januari 2020, antara fatwa negeri yang telah diseragamkan dan diselaraskan walaupun dengan beberapa pindaan struktur ayat dan dalil-dalil ialah Pandangan Hukum Berkenaan Penilaian Semula Nilai Altitud Matahari di Bawah Ufuk Bagi Penentuan Awal Waktu Solat Subuh di Malaysia, Penambahbaikan Pandangan Hukum Berkenaan Pendermaan Organ dan Tisu, Pengharaman Kumpulan Hizbut Tahrir, Kedudukan Perbuatan Zikir Sambil Memukul Gendang Atau Peralatan Muzik Lain dalam Masjid Atau Surau, Pematuhan Syariah Skim Sijil Simpanan Premium Bank Simpanan Nasional (BSN), Kewajaran Mewajibkan Pelaksanaan Ujian Saringan HIV Kepada Bakal Pengantin dan lain-lain.

Bahagian Penyelidikan (sebelumnya di bawah Bahagian Pengurusan Istinbat/Bahagian Pengurusan Fatwa) juga telah mengambil inisiatif melaksanakan Bengkel Penyeragaman Sighah Fatwa. Bengkel ini telah dilaksanakan sepanjang tahun 2015-2018 bagi memenuhi program "menyeragamkan sighah pewartaan fatwa menepati kehendak undangundang" di bawah Teras 1 Strategi 4 Program 15 Pelan Strategik JAKIM 2015-2019. Isu ini bertitik tolak daripada cabaran yang dilontarkan dalam Pelan Strategik Jabatan-Jabatan Mufti Seluruh Malaysia 2010-2014 agar penyeragaman akta/enakmen antara negeri-negeri dapat direalisasikan agar 
akhirnya penyelarasan fatwa turut dapat direalisasikan kerana perkara ini bukanlah suatu yang mustahil untuk dilaksanakan. Sehingga tahun 2018, Urus setia Jawatankuasa Muzakarah MKI telah menyeragamkan sebanyak 79 Pandangan Hukum Muzakarah MKI untuk pewartaan pada peringkat Negeri. Semua draf sighah tersebut telah dihantar ke Jabatan Mufti Negerinegeri untuk dibincangkan pada peringkat Jawatankuasa Fatwa Negeri untuk penerimaan dan pewartaan.

Bahagian Pengurusan Fatwa juga pernah mengeluarkan Garis Panduan Pemakaian Keputusan/ Pandangan Hukum Yang Dibuat Oleh Jawatankuasa Fatwa MKI Sebagai Fatwa Negeri. Garis Panduan ini telah diperakui oleh Jawatankuasa Muzakarah MKI dan telah diedarkan kepada Jabatan-Jabatan Mufti Seluruh Malaysia.

Penganjuran Multaqa AJK Fatwa Seluruh Malaysia yang diadakan pada 21-23 September 2020 anjuran Jabatan Kemajuan Islam Malaysia yang menjadi urus setia Mesyuarat Jawatankuasa Muzakarah MKI menjadi titik tolak penting kepada penyeragaman dan penyelarasan fatwa di Malaysia. Ghazali (2020), mantan Ketua Pengarah Jabatan Kehakiman Syariah yang juga merupakan Ahli Muzakarah Yang Dilantik Majlis RajaRaja telah mengemukakan saranan yang autentik bagi pelaksanaan fatwa yang seragam dan selaras. Antara lain beliau mencadangkan:

1. Pindaan peruntukan undang-undang dalam Akta/Enakmen/Ordinan Pentadbiran Agama Islam Negeri dan yang berkaitan dengan fatwa dengan memasukkan penerimaan Jawatankuasa Fatwa Negeri terhadap pandangan hukum Jawatankuasa Muzakarah MKI.

2. Jawatankuasa Fatwa Negeri hendaklah menerima tanpa menolak pandangan hukum yang diputuskan oleh Jawatankuasa Muzakarah MKI dalam isu yang melibatkan kepentingan nasional.

3. Penyelarasan fatwa yang mempunyai kepentingan bersama hendaklah menjadi agenda utama para mufti dan ahli jawatankuasa fatwa untuk memutuskan sesuatu fatwa pada peringkat negeri.

4. Setiap fatwa yang dikeluarkan oleh Jawatankuasa Fatwa Negeri hendaklah diwartakan.

5. Menerima pakai Garis Panduan Pengeluaran Fatwa di Malaysia yang telah digubal dan telah disemak oleh Darul al-Ifta', Republik Arab Mesir serta diperakui oleh Muzakarah Jawatankuasa MKI.

6. Menerima pakai draf sighah hukum yang telah diseragamkan 
untuk tujuan pewartaan pada peringkat negeri melalui Bengkel Penyeragaman Sighah Bahagian Penyelidikan JAKIM.

Malah beliau turut memetik bahawa hukum syarak dan fatwa berkaitan COVID-19 yang disepakati dalam Muzakarah Khas dan diterima pada peringkat negeri menjadi penanda aras yang jelas, keselarasan dan keseragaman fatwa ialah satu realiti dan bukannya retorik.

\section{PENYELARASAN FATWA COVID-19 DI MALAYSIA}

Seperti yang telah dijelaskan dalam perbincangan terdahulu, Jawatankuasa Muzakarah Khas telah mengeluarkan beberapa pandangan hukum berkaitan dengan pelaksanaan ibadah orang-orang Islam impak COVID-19. Jadual 1 mengemukakan perincian berkenaan dengan penerimaan dan pelaksanaannya negeri-negeri di Malaysia.

\section{DAPATAN KAJIAN}

Jadual 1 Keputusan Jawatankuasa Muzakarah Khas MKI berkaitan dengan pelaksanaan ibadah orang-orang Islam impak COVID-19.

\begin{tabular}{|l|l|l|l|}
\hline Bil & Keputusan Muzakarah & $\begin{array}{l}\text { Tarikh } \\
\text { Muzakarah }\end{array}$ & $\begin{array}{l}\text { Pelaksanaan } \\
\text { Fatwa Negeri- } \\
\text { negeri }\end{array}$ \\
\hline 1. & $\begin{array}{l}\text { Penangguhan semua aktiviti masjid dan } \\
\text { surau termasuk solat berjemaah dan solat } \\
\text { Jumaat. }\end{array}$ & 15 Mac 2020 & $\begin{array}{l}\text { Difatwakan di } \\
\text { semua negeri }\end{array}$ \\
\hline 2. & $\begin{array}{l}\text { Tatacara Pengurusan Jenazah orang islam } \\
\text { yang disyaki atau disahkan dijangkiti } \\
\text { virus COVID-19 (Corona Virus) di } \\
\text { Malaysia. }\end{array}$ & 15 Mac 2020 & $\begin{array}{l}\text { Difatwakan di } \\
\text { semua negeri }\end{array}$ \\
\hline 3. & $\begin{array}{l}\text { Kaedah melihat anak bulan Ramadan, } \\
\text { Syawal dan Zulhijjah ketika Perintah } \\
\text { Kawalan Pergerakan (PKP- COVID19). }\end{array}$ & 9 April 2020 & $\begin{array}{l}\text { Difatwakan di } \\
\text { semua negeri }\end{array}$ \\
\hline 4. & $\begin{array}{l}\text { Penyelarasan kaedah pembayaran zakat } \\
\text { fitrah dalam tempoh Perintah Kawalan } \\
\text { Pergerakan (PKP- COVID19). }\end{array}$ & 9 April 2020 & $\begin{array}{l}\text { Difatwakan di } \\
\text { semua negeri }\end{array}$ \\
\hline 5. & $\begin{array}{l}\text { Kaedah solat Jumaat dan ibadah bulan } \\
\text { Ramadan sepanjang tempoh Perintah } \\
\text { Kawalan Pergerakan (PKP-COVID19). }\end{array}$ & 9 April 2020 & $\begin{array}{l}\text { Difatwakan di } \\
\text { semua negeri }\end{array}$ \\
\hline
\end{tabular}




\begin{tabular}{|c|c|c|c|}
\hline Bil & Keputusan Muzakarah & $\begin{array}{l}\text { Tarikh } \\
\text { Muzakarah }\end{array}$ & $\begin{array}{l}\text { Pelaksanaan } \\
\text { Fatwa Negeri- } \\
\text { negeri }\end{array}$ \\
\hline 6. & $\begin{array}{l}\text { Panduan hukum ujian saringan dan } \\
\text { prosedur rawatan pesakit COVID-19 pada } \\
\text { bulan Ramadan. }\end{array}$ & 21 April 2020 & $\begin{array}{l}\text { Difatwakan di } \\
\text { semua negeri }\end{array}$ \\
\hline 7. & $\begin{array}{l}\text { Hukum puasa kerana menjalani ujian } \\
\text { saringan perubatan COVID- } 19 \text {. }\end{array}$ & 21 April 2020 & $\begin{array}{l}\text { Difatwakan di } \\
\text { semua negeri }\end{array}$ \\
\hline 7. & $\begin{array}{l}\text { Kedudukan saf solat jemaah ketika } \\
\text { Perintah Kawalan Pergerakan (PKP) } \\
\text { COVID-19. }\end{array}$ & 21 April 2020 & $\begin{array}{l}\text { Difatwakan di } \\
\text { semua negeri }\end{array}$ \\
\hline 8. & $\begin{array}{l}\text { Garis panduan sambutan hari raya ketika } \\
\text { Perintah Kawalan Pergerakan (PKP) } \\
\text { COVID-19. }\end{array}$ & 21 April 2020 & $\begin{array}{l}\text { Difatwakan di } \\
\text { semua negeri }\end{array}$ \\
\hline 9. & $\begin{array}{l}\text { Garis panduan solat fardu dan sunat secara } \\
\text { berjemaah dalam tempoh pasca-PKP } \\
\text { COVID-19 }\end{array}$ & 30 April 2020 & $\begin{array}{l}\text { Difatwakan di } \\
\text { semua negeri }\end{array}$ \\
\hline 10. & $\begin{array}{l}\text { Garis panduan solat Jumaat dalam tempoh } \\
\text { Perintah Kawalan Pergerakan Bersyarat } \\
\text { (PKPB) COVID-19. }\end{array}$ & 8 Mei 2020 & $\begin{array}{l}\text { Difatwakan di } \\
\text { semua negeri }\end{array}$ \\
\hline 11. & $\begin{array}{l}\text { Cadangan aktiviti di masjid dan surau } \\
\text { dalam tempoh Perintah Kawalan } \\
\text { Pergerakan Pemulihan (PKPP) } \\
\text { COVID-19. }\end{array}$ & 9 Jun 2020 & $\begin{array}{l}\text { Difatwakan di } \\
\text { semua negeri }\end{array}$ \\
\hline 12. & $\begin{array}{l}\text { Garis panduan pelaksanaan ibadah } \\
\text { korban dalam tempoh Perintah Kawalan } \\
\text { Pergerakan Pemulihan (PKPP). }\end{array}$ & 9 Jun 2020 & $\begin{array}{l}\text { Difatwakan di } \\
\text { semua negeri }\end{array}$ \\
\hline 13. & $\begin{array}{l}\text { Pelaksanaan haji bagi musim haji } 1441 \\
\text { Hijrah }(2020) \text { berikutan penularan } \\
\text { COVID-19. }\end{array}$ & 9 Jun 2020 & $\begin{array}{l}\text { Difatwakan di } \\
\text { semua negeri }\end{array}$ \\
\hline 14. & $\begin{array}{l}\text { Pelaksanaan solat Jumaat dalam tempoh } \\
\text { Perintah Kawalan Pergerakan Pemulihan } \\
\text { (PKPP) COVID-19. }\end{array}$ & 24 Jun 2020 & $\begin{array}{l}\text { Difatwakan di } \\
\text { semua negeri }\end{array}$ \\
\hline
\end{tabular}

(Sumber: Pengkaji dengan merujuk Keputusan Muzakarah Khas berkaitan dengan pelaksanaan ibadah orang-orang Islam Impak COVID-19) 
Usaha penyeragaman fatwa di Malaysia telah lama dirintis. Penubuhan Jawatankuasa Muzakarah MKI adalah antara impak yang dilihat berkesan dalam penyelarasan fatwa sebagai forum yang menghimpunkan semua mufti negeri dalam satu wadah perbincangan. Peruntukan undang-undang Islam di negeri-negeri sendiri telah membuka ruang untuk penyelarasan fatwa berhubung hukum syarak dalam isu COVID-19 ini yang memberikan isyarat bahawa pandangan hukum Jawatankuasa Muzakarah MKI diterima secara baik dan rasional pada peringkat negeri. Islam tetap meraikan khilaf, tetapi dalam perkara yang melibatkan kepentingan awam pertikaian yang tidak mendatangkan keuntungan kepada ummah diketepikannya.

Dapatan utama yang diperoleh melalui kajian digarapkan dalam bentuk fakta seperti di bawah:

1. Fatwa berkaitan dengan COVID-19 dalam isu ibadat telah dibentangkan pada peringkat awal dalam Mesyuarat Jawatankuasa Muzakarah Khas MKI yang diurusetiakan oleh Jabatan Kemajuan Islam Malaysia, atas kapasitinya sebagai badan penyelaras fatwa pada peringkat Kebangsaan. Semua hukum dan keputusan yang dipersetujui dalam Muzakarah Khas ini diterima bagi tujuan pelaksanaan di negerinegeri.

2. Prinsip asas dan utama yang membolehkan penyelarasan ini berlaku adalah dengan merujuk isu-isu hukum yang berkepentingan nasional. Dalam isu COVID-19 ini, yang merupakan isu negara, maka sewajarnya pandangan hukum yang diputuskan pada peringkat Kebangsaan diterima terus oleh jawatankuasa fatwa negeri.

3. Rujukan undang-undang Islam Negeri yang berautoriti seperti yang diperuntukkan antaranya termasuklah "Fatwa yang ada hubungan dengan kepentingan nasional" dan "Menerima pakai nasihat dan syor Jawatankuasa Fatwa Kebangsaan" ialah peruntukan paling absah untuk memperakukan kebolehlaksanaan penyelarasan dan penyeragaman fatwa di Malaysia.

4. Semua peruntukan undang-undang Islam negeri berkaitan dengan fatwa mempunyai peruntukan "Fatwa yang ada hubungan dengan kepentingan nasional". Peruntukan ini memudahkan proses dan prosedur penerimaan keputusan Muzakarah sebagai fatwa di negeri.

5. Walaupun lima negeri, iaitu Wilayah Persekutuan, Kelantan, 
Terengganu, Pahang dan Negeri Sembilan tidak mempunyai peruntukan "Menerima pakai nasihat dan syor Jawatankuasa Fatwa Kebangsaan", namun fatwa tentang COVID-19 tetap diterima dan dilaksanakan sama seperti negeri-negeri lain yang mempunyai peruntukan tersebut.

6. Penyelarasan fatwa bukanlah suatu yang bersifat retorik kerana diperuntukkan dalam peruntukan undang-undang Islam yang berjalan di Malaysia. Penyelarasan fatwa amat bertepatan dengan konsep federalisme melalui pembahagian bidang kuasa seperti yang diperuntukkan Perlembagaan Persekutuan

\section{KESIMPULAN}

Penyelarasan dan penyeragaman fatwa mampu direalisasikan melalui kombinasi harmoni dan kerjasama baik antara kedua-dua institusi fatwa, sama ada pada peringkat kebangsaan mahupun negeri. Jawatankuasa Muzakarah sebagai badan penyelaras, manakala Jawatankuasa Fatwa Negeri sebagai pelaksana dapat memanfaatkan peruntukan sedia ada dalam isu yang membabitkan kepentingan nasional.

Sewajarnya forum Muzakarah ini hanya membincangkan isu-isu nasional dan bersifat kontemporari bagi manfaat umat Islam secara keseluruhan yang menyentuh persoalan berkaitan dengan dasar, polisi, program atau aktiviti Kerajaan Persekutuan, Kerajaan Negeri atau manamana kementerian, jabatan atau agensi.

Setiap keputusan yang dikeluarkan oleh Jawatankuasa Muzakarah MKI hendaklah diiktiraf sebagai pandangan hukum yang mempunyai kredibiliti dan berautoriti. Pihak Negeri mestilah mempunyai inisiatif dan kesungguhan tinggi untuk memartabatkan fatwa sehingga diyakini oleh semua pihak sama ada masyarakat Islam, pemerintah dan institusi kehakiman. Maka apabila timbul polemik, adakah keputusan Muzakarah boleh dilaksanakan pada peringkat negeri, pengkaji cenderung menyatakan bahawa hal ini dibolehkan kerana tiada sebarang peruntukan yang menghalang penyelarasan dan penyeragaman itu berlaku.

Perkara ini dijelaskan melalui arahan pentadbiran Jawatankuasa Muzakarah MKI yang mensyaratkan bahawa perkara yang dibincangkan dalam Muzakarah hendaklah masalah-masalah keagamaan yang bukan bersifat tempatan tetapi berkaitan dengan hal ehwal umat Islam secara keseluruhannya. Oleh itu, adalah lebih baik, setiap pandangan hukum yang 
dilihat mempunyai kepentingan nasional serta melibatkan kemaslahatan umat Islam di Malaysia yang dikeluarkan oleh Jawatankuasa Muzakarah MKI hendaklah diiktiraf sebagai keputusan yang mempunyai kredibiliti dan berautoriti. Pihak Negeri mestilah mempunyai inisiatif dan kesungguhan tinggi untuk memartabatkan fatwa sehingga diyakini oleh semua pihak, iaitu masyarakat Islam, pemerintah dan institusi kehakiman.

\section{RUJUKAN}

Ahmad Hidayat Buang. (2012). Ke arah membangun garis panduan dan piawaian pengeluaran fatwa di Malaysia. Nilai: Universiti Sains Islam Malaysia. Muzakarah Pakar: Garis Panduan dan Piawaian Pengeluaran Fatwa Peringkat Kebangsaan. Anjuran Universiti Sains Islam Malaysia, Nilai 24 Oktober.

Akta Pencegahan dan Pengawalan Penyakit Berjangkit 1988

Akta Polis 1967

Arik Sanusi, Y. J. (2010). Penyelarasan fatwa di Malaysia: Kekangan dari aspek perundangan. Monograf al-Ifta', 1(7), 74-86

Enakmen Fatwa Negeri Sabah (2004)

Enakmen Mufti dan Fatwa Kedah Darul Aman (2008)

Enakmen Pentadbiran Agama Islam Negeri Johor (2003)

Enakmen Pentadbiran Agama Islam Negeri Melaka (2002)

Enakmen Pentadbiran Agama Islam Negeri Pulau Pinang (2004)

Enakmen Pentadbiran Agama Islam Negeri Selangor (2003)

Enakmen Pentadbiran Agama Islam Negeri Sembilan (2003)

Enakmen Pentadbiran Agama Islam Perak (2004)

Enakmen Pentadbiran Agama Islam Perlis (2006)

Enakmen Pentadbiran Undang-Undang Islam Pahang (1991)

Enakmen Pentadbiran Undang-Undang Islam Sabah (1992)

Ghazali Abdul Rahman. (2020). Peranan Jawatankuasa Fatwa dalam Menyelaraskan Fatwa Antara Negeri. Sepang: Hotel Sama-Sama. Multaqa Jawatankuasa Fatwa Seluruh Malaysia. Sepang 21-23 September.

Harding, J. (2013). Qualitative data analysis: From start to finish. Sage Publications Ltd.

Kompilasi Pandangan Hukum Jawatankuasa. (2018). Muzakarah Kebangsaan (Majlis Kebangsaan Bagi Hal Ehwal Ugama Islam Malaysia). Jabatan Kemajuan Islam Malaysia.

Lokmanulhakim Hussain. (2013). Penyelarasan fatwa di Malaysia: Kewajaran dan kekangan. Universiti Sains Islam Malaysia.

Mahamad Naser Disa. (2011). Ke arah penyelarasan dan penyatuan pandangan dalam pengeluaran hukum di Malaysia : Perspektif Perundangan. Monograf Al-Ifta', 2(5), 89-106. Jabatan Kemajuan Islam Malaysia. . 
Merriam, S.B. (2009). Qualitative research: A guide to design and implementation. Jossey-Bass.

Mohamed Azam, M. A. (2012). Penyelarasan Fatwa : Isu, Masalah dan Harapan. Kertas kerja Seminar Kebangsaan Penyelarasan Penguatkuasaan Fatwa di Malaysia 2012. Anjuran Universiti Sains Islam Malaysia \& Jabatan Kemajuan Islam Malaysia. Nilai Negeri Sembilan, 12 April.

Mohd Hamzah, I. (2014). Kesan Ketidakseragaman Fatwa : Pandangan Dari Sudut Undang-Undang. Kertas Kerja Bengkel Penyelarasan Pengurusan Fatwa Jabatan Mufti Seluruh Malaysia. Anjuran Jabatan Kemajuan Islam Malaysia, Shah Alam.

Mohd. Mohadis Yasin. (2007). Pengurusan dan Penyelarasan Fatwa: Pelaksanaan dan Cabaran di Malaysia. Jurnal Pengurusan Dan Penyelidikan Fatwa, 1(1), $119-135$

Muhamad Miziazam, Y., Mansor, S., \& Hasan, A. (2018). Penyelarasan fatwa dan kaedah penyelesaiannya di Malaysia: Suatu kajian literatur. International Journal of Humanities Technology and Civilization (IJHTC). Universiti Malaysia Pahang Press. Issue 4. 1, December, 22-35;

Muhammad Fathullah Al Haq, M. A., \& Jasni, S. (2017). Penyelarasan fatwa antara negeri-negeri: Analisis amalan dan kaedah penyeragamannya di Malaysia. Jurnal Pengurusan dan Penyelidikan Fatwa, 9, 86-109.

Muhammad Ikhlas Rosele, Luqman, A., Paizah, I., \& Mohd Anuar Ramli. (2013). Konflik Fatwa di Malaysia: Satu Kajian Awal. Jurnal Syariah, 10 (10), hlm. 31-56

Pelan Strategik Jabatan-Jabatan Mufti Seluruh Malaysia (2010-2014). Putrajaya: Jabatan Kemajuan Islam Malaysia.

Pelan Strategik JAKIM (2015-2019). Putrajaya: Jabatan Kemajuan Islam Malaysia.

Peraturan Majlis Kebangsaan Bagi Hal Ehwal Ugama Islam Malaysia. (2013).

Perlembagaan Persekutuan. (2006). International Law Book Services.

Zaini Nasohah. (2005). Undang-undang penguatkuasaan fatwa di Malaysia. Jurnal Islamiyyat, 27(1), 25-43.

Zulfaqar Mamat. (2013). Muzakarah Jawatankuasa Fatwa Majlis Kebangsaan bagi Hal Ehwal Ugama Islam Malaysia: Kajian terhadap penerimaan dan penolakan di peringkat negeri (Tesis Dr. Falsafah tidak diterbitkan). Universiti Kebangsaan Malaysia. 